\title{
Histopathological and Histometrical Assessment of Boron Exposure Effects on Mouse Spermatogenesis
}

\author{
Evaluación Histopatológica e Histométrica del Efecto \\ en la Espermatogénesis por Exposición a Boro
}

Bustos-Obregon, E; Carvallo, M; Hartley-Belmar, R; Sarabia, L; Ponce, C.

BUSTOS-OBREGON, E; CARVALLO, M; HARTLEY-BELMAR, R; SARABIA, L; PONCE, C. Histopathological and histometrical assessment of borom exposure effects on mouse spermatogenesis. Int.J. Morphol., 25(4):919-925, 2007.

SUMMARY: Boron is a chemical element widely used in many industrial activities. Exposure to it affects many organs in mammals, mainly reproductive male organs. This work evaluates boron effect in testis. For this purpose, $12 \mathrm{mg}$ Boron/L of drinking water, equivalent to Arica tap water, was given for 42 days to 85 days old CF1 male mice (experimental group). Another group (control group) drunk tap water of Santiago $(0.6 \mathrm{mg}$ Boron/L) was used. Testicular histopathology and morphometric analysis was done. These studies showed that Borum induces alterations such as epithelial vacuolization, blockage of the tubular lumen and atrophy. Morphometrical data showed that Borom induces also enlargement of tubular diameter, epithelial height and tubular lumen. Therefore, it is concluded that Boron acts as testicular toxicant and that further studies are needed to establish its mechanism of action upon spermatogenesis.

KEY WORDS: Boron; Testicular histopathology; Morphometry; Mouse spermatogenesis.

\section{INTRODUCTION}

Boron is a chemical element that exists in natural form in the environment combined with oxygen and other elements. Boron forms compounds known as borates or acids (Dixon et al., 2005).

Aside from natural sources, Boron is also released by human activities, being incorporated to the environment as a result of the use of borates and perborates in domestic and industrial uses as different products containing this mineral, like fiberglass, borosilicate glass, detergents, fertilizers and agricultural herbicides. Both the usage of boroncontaining fertilizers and herbicides as well as the burning of products of vegetal origin generate contaminating residues from the extraction and processing of borates, from residual waters and their muds. (IPCS/OMS, 1998).

Boron is considered detrimental for humans when it exceeds the allowed limits described by the WHO for water concentration, ranging from $0.6 \mathrm{mg} / \mathrm{L}$ of water to $1 \mathrm{mg} / \mathrm{L}$ of water (IPCS/OMS, 1998). According to analyses in the city of Arica (northern Chile), boron concentrations range from
6 to $15 \mathrm{mg} / \mathrm{L}$ in tap water, excessively surpassing the WHO recommendation (Figueroa, 2002).

Boron acts in the same form in human beings and in other mammals, such as mouse and rats.

When ingested or inhaled and after its liver metabolism, boron is widely distributed throughout the organism and is incorporated by bones; later it is quickly excreted as metabolites but slowly eliminated from bones. In laboratory animals, Boron affects reproduction and normal development of the foetus (Espinoza-Navarro et al., 2006). This effect would be associated to alterations on spermatogenesis as evidenced by low sperm count findings.

Spermatogenesis. Spermatogenesis is a process that occurs in testis, specifically in the seminiferous tubules, concluding with the formation of spermatozoa.

In spermatogenesis, three main phases are distinguished: the first (mitotic stage), in which 
spermatogonial proliferate in number and generate primary spermatocytes; in the second (meiotic phase), primary spermatocytes undergo genetic recombination and secondary spermatocytes are generated which afterwards will differentiate into spermatids; the third phase (spermiogenesis), where cell differentiation processes happen, result in the characteristic sperm morphology for each species (Gartner \& Hiatt, 1997).

In most species, a group of spermatogonia remains as a reservoir (stem cells) in each proliferative cycle giving continuity to sperm production during the male reproductive life (Clermont \& Bustos-Obregon, 1966).

In the mouse, spermatogenesis begins in the fetal period, when the seminiferous tubules contain mature Sertoli cells and gonocytes. In the initial stages, meiosis begins 14 days after birth, the first spermatids appear after 23 days (in average), and so by the 28th day there is a qualitatively complete spermatogenesis but with an inadequate sperm concentration to produce fertilization (Sobarzo \& BustosObregon, 2000).

It is important to emphasize that in mouse there are 12 stages in the production of mature spermatozoa (Fig. 1), with each stage occupying small segments in the seminiferous epithelium and thus continuing the maturation in each stage. The complete series of stages of the seminiferous epithelium constitutes a cycle, which in mouse equals to 8.45 days and 33 days for total spermatogenesis (Leblond \& Clermont, 1952).

Finally, spermatozoa are the product of the spermatogenic process (generated during spermiogenesis); they are long-shaped cells of $65 \mu \mathrm{m}$ of length comprised of a head (where the acrosome and the genetic material reside), an intermediate segment (containing mitochondria) and a tail that is the longest portion and provides motility (Gartner \& Hiatt).

Seminiferous tubules. Mouse seminiferous tubules are approximately 220 microns of diameter; their overall length is close to two meters and placed one after another they can reach 250 meters approximately. These tubules are specialized in sperm production.

The tubular compartment of the testis is represented by the seminiferous tubules, which continue in a short straight terminal segment called tubules rectus, structures which anatomise and thus form the rete testis (Geneser, 2000). Within the seminiferous tubules, cells are associated in an organized and predetermined architecture, with a wall composed by connective tissue on which the seminiferous epithelium rests (Tchernitchin, 1995).

In seminiferous tubules, the seminiferous epithelium is formed by two types of cells: Sertoli and spermatogenic cells. The latter ones are in constant proliferation and maturation for the formation of new spermatozoa (Arrau et al., 1981).

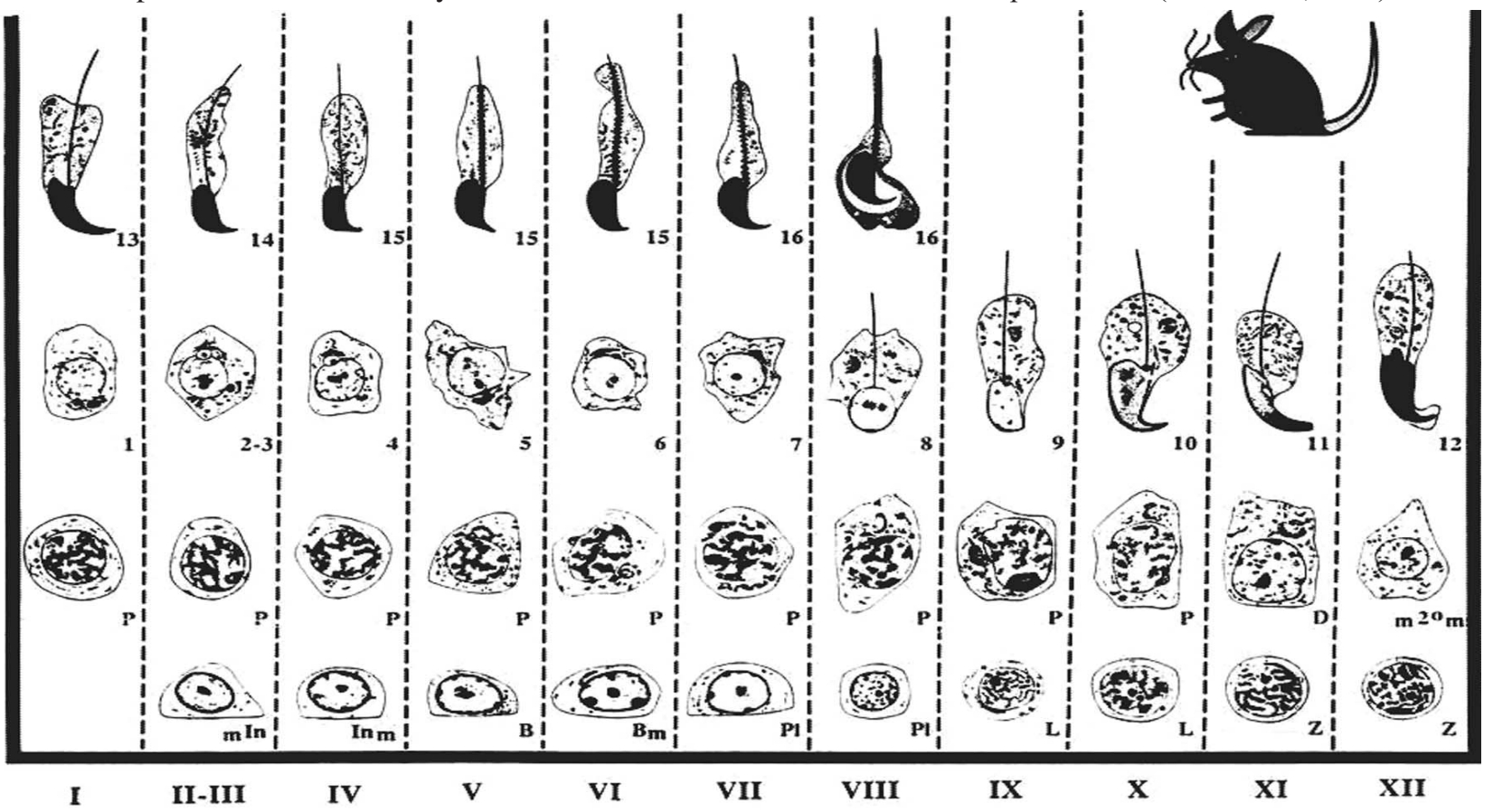

STAGES OF THE CYCLE

Fig. 1. Diagram of the 12 stages for the production of spermatozoa in the mouse seminiferous epithelium (Russell et al., 1990). 
The peritubular compartment of the testicle is formed by extracellular matrix and -in mice- by a single layer of flattened cells denominated myoid cells. This compartment is separated from the seminiferous epithelium by the basal lamina.

The connective tissue itself corresponds to the interstitial compartment of the testicle which occupies the intertubular spaces, corresponding to lose connective tissue in which blood and lymph vessels, fibroblasts, Leydig cells (those that produce testosterone), elastic fibers, collagen type I and reticular fibers (Tchernitchin).

The present work deals with an histopathological and histometrical assessment of boron exposure effects on mouse spermatogenesis, assuming that the exposure of mice (Mus musculus) to high doses of boron induces alterations in the normal development of spermatogenesis.

\section{MATERIAL AND METHOD}

Biological material. Animals: 20 adult male mice (Mus musculus, CF-1 strain) of 85 days of age and sexually mature were selected from our animal house, fed with commercial pellet and water ad libitum with a $12 \mathrm{~h}: 12 \mathrm{~h}$ light-dark cycle. Mice were randomly divided into 2 groups of 10 individuals each. One group consumed tap water from Santiago de Chile (control group; $0.6 \mathrm{mg}$ of boron/L) and the other group was exposed to $12 \mathrm{mg}$ of boron/ $\mathrm{L}$ in drinking water during 42 days (from day 85 to day 127 of age), simulating the human consumption of the metalloid by the population in Arica.

After treatment, animals were anaesthetized with ether and blood samples were collected by cardiac puncture using a heparinized syringe to analyze serum boron levels using the Boron Test Kit (Merck; Darmstadt, Germany). Animals were finally sacrificed by prolonged exposure to ether after 42 days of treatment (age: 127 days). The testicles were removed and processed for histological and morphometric analysis. Histological techniques, morphometric analysis of seminiferous tubules and sperm count were performed on testes and cauda epididymides from both groups,

Histological Techniques. Testis processing: The testis was fixed in alcoholic Bouin for 24 hours, and then process for routine paraffin embedding and H-E staining. Testis crosssections were obtained, selecting one every ten successive 5 $\mu \mathrm{m}$-thick sections.

Morphometric Techniques: By means of morphometrical techniques, quantitative information on the variations observed in relation to seminiferous epithelium height, seminiferous tubule diameter and tubular lumen variations were recorded (Wing \& Christensen, 1982). For each slide (controls and boron-exposed samples) 200 tubules were analyzed, using digitalized microscopic images (10X), with the software Image Tools 3.0 (obtained from http:// ddsdx.uthsca.edu/dig/itdesc.html).

Sperm extraction and count from cauda epididymis. A sperm suspension from tail (cauda) of epididymis was obtained (Bustos-Obregon et al., 2006). Approximately 15 $\mu \mathrm{L}$ of the diluted sample were transferred to a Neubauer chamber. Sperm counting must include complete spermatozoa only (head and tail). Loose heads must be counted separately.

Evaluations. Histological samples were analyzed using optical microscopy, considering the following testicular characteristics:

Morphometry: It included tubule diameter, seminiferous epithelial height and tubular lumen diameter. Round-shaped seminiferous tubules were measured using a $10 \mathrm{X}$ objective and fields were calibrated using a micrometric eyepiece.

Histopathology: Epithelial discontinuity and vacuolization, cell degeneration and peritubular tissue alterations were evaluated. Tubular counting was performed under a $4 \mathrm{X}$ objective while histopathological changes were assayed using a 10X objective.

Statistical analysis: The obtained values, percentages and indexes were statistically analyzed to determine the significance of the differences between groups using the non-parametric Kruskal-Wallis test.

\section{RESULTS}

The present work evaluates and compares the histological and morphometrical analysis of testicular tissue samples obtained from adult male CF-1 mice that were exposed to $12 \mathrm{mg}$ of Boron per liter of drinking water since day 85 of age and during 42 continuous days (until the $127^{\text {th }}$ day of age) with those from a similar control group which was given regular tap water obtained from Santiago de Chile during the same time.

The results demonstrate differences between the Boron-exposed groups and the control group. The obtained measurements are expressed for each group in the following tables and charts and statistical analysis was done using the 
GraphPad Instat software and applying the non-parametric Kruskal-Wallis test. A p-value $\leq 0.05$ was considered statistically significant.

With regard to the histopathology, the Boron-exposed group exhibits a $27 \%$ of histological changes, with a $2 \%$ of tubular atrophy, a $7 \%$ of tubular obstruction and an $18 \%$ of epithelial vacuolization. In the control group, damage was less than $1 \%$.

Tubular diameter. A minimum of 600 measurements per each individual for tubular diameter was considered (Table I). The obtained morphometrical results indicate that the average tubular diameter in Boron-exposed individuals is significantly greater than those in the control group.

Table I. Mean tubular diameter \pm standard error (SE) per individual. $(n=6000 ; p=0,0479)$

\begin{tabular}{cc}
\hline CONTROLS & EXPOSED \\
\hline $209,8 \pm 5,76(\mathrm{n}=600)$ & $217,9 \pm 9,91(\mathrm{n}=600)$ \\
$205,8 \pm 5,76(\mathrm{n}=600)$ & $214,2 \pm 9,91(\mathrm{n}=600)$ \\
$194,9 \pm 5,76(\mathrm{n}=600)$ & $214,6 \pm 9,91(\mathrm{n}=600)$ \\
$259,1 \pm 5,76(\mathrm{n}=600)$ & $247,2 \pm 9,91(\mathrm{n}=600)$ \\
$207,1 \pm 5,76(\mathrm{n}=600)$ & $208,5 \pm 9,91(\mathrm{n}=600)$ \\
$202,6 \pm 5,76(\mathrm{n}=600)$ & $202,2 \pm 9,91(\mathrm{n}=600)$ \\
$205,3 \pm 5,76(\mathrm{n}=600)$ & $268,5 \pm 9,91(\mathrm{n}=600)$ \\
$200,9 \pm 5,76(\mathrm{n}=600)$ & $211,2 \pm 9,91(\mathrm{n}=600)$ \\
$206,6 \pm 5,76(\mathrm{n}=600)$ & $297,1 \pm 9,91(\mathrm{n}=600)$ \\
$197,3 \pm 5,76(\mathrm{n}=600)$ & $251,5 \pm 9,91(\mathrm{n}=600)$ \\
\hline
\end{tabular}

Seminiferous epithelium height. A minimum of 400 measurements per each individual was considered (Table II). According to the data presented, a tendency to augmentation in this parameter for the Boron-exposed group is seen when compared to the control group.

Tubular lumen. A minimum of 200 measurements per each individual was considered (Table III). Regarding tubular lumen, the results show variations at this level indicating increase of the luminal area in the Boron-exposed group compared to the control.

Sperm count. Expressed in sperm per mg of cauda epididymis (Table IV); the sperm count of 8 mice per group was considered. Results showed that in individuals exposed to Boron, the amount of spermatozoa in the cauda epididymal reserve is comparatively low when compared to that of the control group.
Table II. Mean height of seminiferous epithelium \pm standard error (SE) per individual. $(n=4000 ; \mathrm{p}=0,0209)$.

\begin{tabular}{cc}
\hline CONTROLS & EXPOSED \\
\hline $55,9 \pm 0,88(\mathrm{n}=400)$ & $52,5 \pm 3,01(\mathrm{n}=400)$ \\
$54,4 \pm 0,88(\mathrm{n}=400)$ & $52,9 \pm 3,01(\mathrm{n}=400)$ \\
$49,1 \pm 0,88(\mathrm{n}=400)$ & $49,0 \pm 3,01(\mathrm{n}=400)$ \\
$47,4 \pm 0,88(\mathrm{n}=400)$ & $61,1 \pm 3,01(\mathrm{n}=400)$ \\
$49,5 \pm 0,88(\mathrm{n}=400)$ & $50,1 \pm 3,01(\mathrm{n}=400)$ \\
$49,3 \pm 0,88(\mathrm{n}=400)$ & $45,8 \pm 3,01(\mathrm{n}=400)$ \\
$48,1 \pm 0,88(\mathrm{n}=400)$ & $65,1 \pm 3,01(\mathrm{n}=400)$ \\
$48,3 \pm 0,88(\mathrm{n}=400)$ & $68,3 \pm 3,01(\mathrm{n}=400)$ \\
$51,9 \pm 0,88(\mathrm{n}=400)$ & $73,9 \pm 3,01(\mathrm{n}=400)$ \\
$50,02 \pm 0,88(\mathrm{n}=400)$ & $64,7 \pm 3,01(\mathrm{n}=400)$ \\
\hline
\end{tabular}

Table III. Mean seminiferous tubule lumen diameter \pm standard error (SE) per individual. $(n=2000 ; p=0,0121)$.

\begin{tabular}{cc}
\hline CONTROLS & EXPOSED \\
\hline $59,4 \pm 1,41(\mathrm{n}=200)$ & $63,1 \pm 4,10(\mathrm{n}=200)$ \\
$72,0 \pm 1,41(\mathrm{n}=200)$ & $60,9 \pm 4,10(\mathrm{n}=200)$ \\
$62,5 \pm 1,41(\mathrm{n}=200)$ & $60,8 \pm 4,10(\mathrm{n}=200)$ \\
$57,7 \pm 1,41(\mathrm{n}=200)$ & $80,4 \pm 4,10(\mathrm{n}=200)$ \\
$56,6 \pm 1,41(\mathrm{n}=200)$ & $65,3 \pm 4,10(\mathrm{n}=200)$ \\
$60,2 \pm 1,41(\mathrm{n}=200)$ & $63,9 \pm 4,10(\mathrm{n}=200)$ \\
$57,2 \pm 1,41(\mathrm{n}=200)$ & $90,5 \pm 4,10(\mathrm{n}=200)$ \\
$58,0 \pm 1,41(\mathrm{n}=200)$ & $70,9 \pm 4,10(\mathrm{n}=200)$ \\
$60,8 \pm 1,41(\mathrm{n}=200)$ & $97,8 \pm 4,10(\mathrm{n}=200)$ \\
$60,6 \pm 1,41(\mathrm{n}=200)$ & $72,3 \pm 4,10(\mathrm{n}=200)$ \\
\hline
\end{tabular}

Table IV. Mean sperm count \pm standard error $(\mathrm{SE})(\mathrm{n}=8)$ expressed as spermatozoa/mg cauda epididymis. ( $\mathrm{p}<0,0001)$.

\begin{tabular}{rc}
\hline CONTROLS & EXPOSED \\
\hline $562016 \pm 62496$ & $43209 \pm 5686,1$ \\
$807428 \pm 62496$ & $72600 \pm 5686,1$ \\
$1010993 \pm 62496$ & $40053 \pm 5686,1$ \\
$1056261 \pm 62496$ & $22503 \pm 5686,1$ \\
$1119120 \pm 62496$ & $54310 \pm 5686,1$ \\
$1015402 \pm 62496$ & $30209 \pm 5686,1$ \\
$974368 \pm 62496$ & $28422 \pm 5686,1$ \\
$967834 \pm 62496$ & $45751 \pm 5686,1$ \\
\hline
\end{tabular}

Table $\mathrm{V}$ shows the overall means and standard error for all the parameters analyzed, for easier comparison of all results. 
Table V. Overall mean \pm standard error (SE) and p-value for the analyzed parameters. $((* *) p \leq 0,05)$

\begin{tabular}{lccc}
\hline \multicolumn{1}{c}{ PARAMETERS } & CONTROLS $(\mu \mathrm{m})$ & EXPOSED $(\mu \mathrm{m})$ & $p$-VALUE \\
\hline TUBULAR DIAMETER $(\mathrm{n}=6000)$ & $208,9 \pm 5,76$ & $233,3 \pm 9,91$ & $* * 0,05$ \\
EPITELIAL HEIGHT $(\mathrm{n}=4000)$ & $50,4 \pm 0,88$ & $58,3 \pm 3,01$ & $* * 0,02$ \\
TUBULAR LUMEN $(\mathrm{n}=2000)$ & $60,5 \pm 1,41$ & $72,6 \pm 4,10$ & $* * 0,01$ \\
\hline
\end{tabular}

\section{DISCUSSION}

Boron is a non-metal capable of exerting injurious action on the reproductive function of mammals and being metabolized in the same form by humans. This similarity justifies the use of animal models, such as rabbits, rats or and mice, to obtain trustworthy predictions of Boron effects in the human species.

In animal studies using mice, rats and rabbits, data related to Boron toxicity describe alterations in body development and reproductive functions. Datum indicates that the most remarkable effect is the low body weight in rats and mice fetuses. The NOAEL (Non-Observed Adverse Effects Level) for the lower body weight was $9.6 \mathrm{mg} / \mathrm{day} /$ $\mathrm{kg}$ of body weight of pregnant females. The lowest concentration with observed adverse effects (LOAEL) in which rats show differences with respect to fetal body weight and anomalies in ribs development is $13 \mathrm{mg}$ of Boron/day $/ \mathrm{kg}$ of body weight. When doses were increased, it was easier to observe deleterious effects like testicular pathology in rats (at $25 \mathrm{mg} /$ day $/ \mathrm{kg}$ b.w.), worsening at $40 \mathrm{mg} / \mathrm{day} / \mathrm{kg}$ b.w. Low body weight of the fetus and increase of fetal cardiovascular malformations in rabbits were observed at $40 \mathrm{mg} / \mathrm{day} / \mathrm{kg}$ b.w. Doses greater than the aforementioned produced testicular atrophy in male rats and reduction of body weight has been recorded in fetuses of exposed mice ( $80 \mathrm{mg}$ of Boron/day/kg b.w.; IPCS/OMS, 1998). A study by Heindel et al. (1991) using boric acid shows similar results. Sub-chronic and chronic oral exposure to boron has demonstrated testicular injuries in laboratory animals fed with food or drinking water containing boric acid or borax (Truhaut et al., 1964; Weir \& Fisher, 1972; Ku et al., 1993a). The clinical signal of testicular toxicity (contracted scrotum) was observed after Boron treatment in dogs, which later exhibited a significant reduction of the absolute and relative testicular weight. After a subchronic Boron exposure, histopathology reveals the inhibition of spermiation and degeneration of the seminiferous tubules with variable loss of germinal cells that finishes in their complete absence and thus resulting in testicular atrophies and transitory or irreversible loss of the fertility without altering reproductive behaviour (libido).
Therefore, it is possible to state that Boron is a reproductive toxicant after exposure to high concentrations of this element (Weir \& Fisher).

Experiments made by Ku \& Chapin (1994) demonstrated in male rats that the first appearing injury is the diminution and inhibition of spermatogenesis. This damage progresses severely up to the disorganization of seminiferous epithelium and generation of immature cells. Tubular atrophy is also described, which only contain residues of spermatogonia and Sertoli cells. In the present study, a histopathological analysis was performed and disorganization of the seminiferous epithelium -as demonstrated by vacuolization and tubular obstruction and atrophy- is evidenced, agreeing with previous findings of $\mathrm{Ku} \&$ Chapin.

It is important to mention that Boron is not the only chemical element that causes reproductive alterations; there are also other metals, e.g. lead and cadmium, which cause similar damages in the reproductive function.

In the literature, there are scarce data related to the seminiferous epithelial cycle and the effects of boron. A specific study made by Silaev \& Kasparov (1977) demonstrated that boric acid in a dose of $1 \mathrm{~g} / \mathrm{kg}$ orally given to rats daily during by a period of 2 weeks induced changes in the nucleus and the cytoplasm of spermatozoa and spermatids. Multinucleated cells with a uniform odd number of nuclei were observed. The formation of multinucleated cells was attributed to the action of boric acid on the prolonged processes of meiotic division.

For a proper spermatogenesis, Leydig cells located in the testicular interstitium and Sertoli cells in testicular parenchyma must participate. The Leydig cell is the main testosterone producer (Dadoune \& Demoulin, 1993). When the testosterone levels diminish, the Sertoli cell activity becomes reduced. Therefore, spermatids and spermatocytes may result affected in their metabolism and differentiation, thus causing alterations in the spermatogenic process. 
Experiments have been performed to examine possible direct influences on testicular integrity. A study made by $\mathrm{Ku}$ et al. (1993b) evaluated some aspects of the testicular system and its cells function after an in vitro exposure to boric acid (BA). No effect of BA on the steroidogenic function of Leydig cells was observed. Nevertheless, there was a slight diminution in the serum testosterone levels. BA did not cause any direct influence on Leydig cells.

In the present study, morphometrical and histological techniques were combined. The morphometrical techniques described by Wing \& Christensen gives information about the alterations on the phases of the rat spermatogenic process; it indicates that as the rat spermatogenesis continues, the measurements made may vary depending on the cycle stage in which the measured tubules are. This explains why intra-group results may be affected by the individuality of every single member of each group in this work. The height of the seminiferous epithelium along the seminiferous tubule in rats initiates its increase after stage $\mathrm{XIV}$ and diminishes in stage $\mathrm{V}$ of the following cycle. There is no information regarding on this topic in the mouse.

Using morphometrical techniques, it was possible to determine the changes caused by the exposure to Boron on the testicular seminiferous tubule morphology, showing morphometrical variations in the exposed group versus the control group. These variations might be associated with an adaptation process in which seminiferous tubules increase their diameter by hypertrophy to compensate the spermatic activity against the histological and degenerative damage evidenced by vacuolization and tubular atrophy.

With a histopathological observation, it was possible to demonstrate alterations in testis morphology such as epithelial vacuolization and tubular obstruction and atrophy in the group exposed to Boron.

Through sperm count results, significant differences in the production of spermatozoa in the group exposed to Boron in relation to the control group were evidenced. The alteration on spermatogenesis was reflected by a low sperm count in the Boron-treated group, a finding that agrees with Weir \& Fisher (1972) who considered Boron as a reproductive toxic.

In this work, the possible relation that could exist between the spermatogenic cycle stage and the morphometrical variations on Boron-exposed mouse seminiferous tubules was not investigated. Therefore, this potential relation may be of interest to be studied in the future to provide more specific data on the damage that Boron exerts on spermatogenesis.

BUSTOS-OBREgON, E; CARVAlLO, M; HARTLEY-BELMAR, R; SARABIA, L; PONCE, C. Evaluación histopatológica e histométrica del efecto en la espermatogénesis por exposición a boro. Int. J. Morphol., 25(4):919-925, 2007.

RESUMEN: El Boro es un elemento químico ampliamente usado en variadas actividades industriales. La exposición a éste afecta a varios órganos en mamíferos, principalmente órganos reproductivos. Este trabajo evaluó los efectos del Boro en testículo. Para este propósito, $12 \mathrm{mg} \quad$ Boro/Lde agua potable, equivalente al agua bebestible de Arica, se administró por 42 días a ratones machos CF1 de 85 días de edad (grupo experimental). Otro grupo (grupo control) bebió agua de Santiago (0.6mg Boro/L). Se realizaron estudios histopatológicos y morfométricos del testículo. Estos estudios mostraron que el Boro induce alteraciones como vacuolización epitelial, taponamiento y atrofia del lumen testicular. Los estudios morfométricos mostraron que el Boro también induce aumento del diámetro tubular, altura del epitelio y del lumen tubular. En consecuencia, se concluye que el Boro actúa como un tóxico testicular y que futuros estudios son necesarios para establecer su mecanismo de acción sobre la espermatogénesis.

PALABRAS CLAVE: Boro; Histopatología testicular; Morfometría; Espermatogenesis de ratón.

\section{REFERENCES}

Arrau, J.; Bustos-Obregón, E.; Hoecker, G. \& Ramos, A. Biología de la Reproducción Animal. Editorial Andrés Bello, Santiago de Chile, 1981.pp. 63-87.

Bustos-Obregón, E.; Esveile, C.; Contreras, J.; Maurer, I. \& Sarabia, L. Effects of chronic simulated hypobaric hypoxia on mouse spermatogenesis. Int. J. Morphol., 24(3):481-8, 2006.
Clermont, Y. \& Bustos, E. identification of live classes of type A spermatogonia in rat seminiferous tubules mounted in toto. Anat. Rec., 154:332-9, 1966.

Dadoune, J. \& Demoulin, A. Structure and functions of the testis. In: Reproduction in mammals and man. Thibault C. \& Levasseur M. (eds). RHF Hunter Elipses, Paris, 1993. pp. 197-225. 
Dixon, R.; Yeng, M. \& Smith, M. Spanish Bottom Line Monograph: Boro. Medical National Library and NIH http://www.nlm.nih.gov/medlineplus/spanish/druginfo/ natural/patient-boron.html, 2005.

Espinoza-Navarro, O.; Vilaxa, A. \& Luque, A. Influencia del boro en parámetros reproductivos masculinos de Drosophila melanogaster. Int. J. Morphol., 24121, 2006.

Figueroa, L. \& Cornejo, L. Impacto ambiental en la ciudad de Arica por la presencia de borato en el agua potable. Área de Química Analítica y ambiental, Facultad de Ciencias, Universidad de Tarapacá. http://www.uta.cl/ investigacion/inf_proyectos.html (2002).

Gartner, L. \& Hiatt, J. Color texbook of histology. W.B: Saunders Company, Philadelphia, Pennsylvania, 1997. pp. 429-32.

Geneser, F. Histología $3^{\circ}$ Ed. Panamericana, Buenos Aires, 2000. Chapter 22. pp. 638-62.

Heindel, J.; Price, C. \& Schwetz, B. The developmental toxicity of boric acid in mice, rats and rabbits. Developmental And Reproductive Toxicology Groups National Program, National Institute Of Enviromental Health Sciences, Research Triangle Park, North Carolina, 1991.

IPCS/OMS. Environmental health criteria for boron. Editorial World Health Organization, Geneva, EHC: 204, 1998.

$\mathrm{Ku}, \mathrm{W}$. \& Chapin, R. The reproductive toxicity of boric acid. Environmental Health Perspectives, 102(7): Health Effects of Boron, pp. 87-91, 1994.

Ku, W.; Chapin, R.; Wine, R. \& Gladen, B. Testicular toxicity of boric acid (BA): Relationship of dose to lesion development and recovery in the F344 rat. Reprod. Toxicol., 4:305-19, 1993.

Ku, W. W.; Shih, L. M. \& Chapin, R. E. The effects of boric acid (BA) on testicular cells in culture. Developmental and Reproductive Toxicology Group, National Institute of Environmental Health Sciences. 7:321-31, 1993.

Leblond, C.\& Clermont, Y. Definition of stages of the cycle of de seminiferous ephitelium in the rat.Ann.N.Y.Acad. Sci., 55:548-73, 1952.
Russel, L.; Ettlin, R.; Sinha, A. \& Clegg, E. Histological and histopathological evaluation of the testis. Cache River Press, Florida, 1990.

Schnaas, L.; Rothenberg, S.; Villanueva-Díaz, C.; Perroni, E.; Hernández, R. \& Hernández, C. Efectos del Plomo sobre la Reproducción. Perinatol.Reprod.Hum., 10:15568, 1996.

Silaev, A.; Kasparov, A.; Korolev, V. \& Nevstrueva, V. Electron microscopic study of the seminiferous tubules of white rats exposed to boric acid. Biull.Eksp. Biol Med., 83:496-9, 1977.

Sobarzo, C. \& Bustos-Obregón, E. Acute effect of parathion on the seminiferous epithelium of immature mice. Rev. Chil. Anat., 18:61-68, 2000.

Tchernitchin, A. Histología. Mediterráneo, Santiago, 1995. pp. 394-7.

Truhaut, R.; Nguyen, P. \& Loisillier, F. On the effects of repeated ingestion of small doses of boron derivatives on the reproductive functions of the rat. CR Health Sciences Acad. Sci., 258:5099-102, 1964.

Weir, R. \& Fisher, R. Toxicologic studies on borax and boric acid. Toxicol. Appl. Pharmacol., 12:351-64, 1972.

Wing, T.; \& Christensen, K. Morphometric studies on rat seminiferous tubules. Am. J. Anat; 165:13-25, 1982.

Correspondence to:

Prof. Dr. Eduardo Bustos-Obregon

POBOX 70061

Santiago - CHILE

Email: ebustos@med.uchile.cl

Received: 31-07-2007

Accepted: 16-10-2007 
